\title{
ANALISIS SISTEM PENERIMAAN PAJAK PARKIR PADA BADAN PENGELOLA PAJAK DAN RETRIBUSI DAERAH KOTA MANADO
}

\author{
Mira Sakke Pamasi ${ }^{1}$, David.P.E.Saerang ${ }^{2}$, Dhullo Afandi ${ }^{3}$ \\ 1,2,3 Jurusan Akuntansi, Fakultas Ekonomi dan Bisnis, Universitas Sam Ratulangi, Jl. Kampus Bahu, Manado, \\ 95115, Indonesia \\ E-mail: pamasi_mira@yahoo.com
}

\begin{abstract}
Parking tax is a local tax imposed under the law number 28 of 2009 on local taxes and user charge. The purpose of this study analyze the adequacyn of the Parking Tax Reception System At the Office of Manado Regional Tax and Retribution Agency. The method used is descriptive analysis. Data were obtained through field studies. The results of this research is the System of Parking Tax Admission in Manado City has been adequate and in accordance with the applicable regulations, namely the Minister of Home Affairs Regulation number 59 at 2007 includes the related functions and documents used as well as the division of tasks and responsibilities. In accordance with the concept of internal control where the collector is divided into several parties that are related and the quality of employees have competence in the field. Therefore, there should be socialization and techincal guidance for employees, especially in the field of accounting for better implementation.

Keywords: Parking Tax Reception
\end{abstract}

\section{PENDAHULUAN}

Pendapatan asli daerah merupakan pendapatan yang bersumber dan dipungut sendiri oleh pemerintah daerah berdasarkann peraturan daerah yang berlaku di Indonesia. Dan semua pendapatan daerah tersebut murni digunakan pemerintah untuk pembangunan daerah demi kesejahteraan masyarakat. Pajak adalah pungutan wajib yang dibayar rakyat untuk negara dan akan digunakan untuk kepentingan pemerintah dan masyarakat umum. Rakyat yang membayar pajak tidak akan merasakan manfaat dari pajak secara langsung, karena pajak digunakan untuk kepentingan umum, bukan untuk kepentingan pribadi. Pajak merupakan salah satu sumber dana pemerintah untuk melakukan pembangunan, baik pemerintah pusat maupun pemerintah daerah. Pemungutan pajak dapat dipaksakan karena dilaksanakan berdasarkan undang-undang.

Dengan adanya otonomi daerah, setiap daerah mempunyai hak dan kewajiban mengatur dan mengurus sendiri urusan pemerintahannya untuk meningkatkan efisiensi dan efektivitas penyelengaraan pemerintahan termasuk penerimaan pajak daerah. Dalam mengelola keuangan daerah unit pemerintahan yakni entitas pelaporan dan entitas akuntansi menyelenggarakan sistem akuntansi pemerintah daerah. Dan faktor yang sangat penting dalam otonomi daerah adalah sistem. Sistem yang diimplementasikan harus mampu menghasilkan data atau informasi yang akurat. Informasi keuangan berupa laporan keuangan, diharapkan dapat memberikan gambaran secara menyeluruh mengenai perkembangan organisasi baik dari sisi prospek dan potensinya sebagai bahan pertimbangan dalam pengambilan keputusan. Sesuai dengan peraturan reformasi keuangan daerah yang ada saat ini, informasi atau data tersebut dapat dikumpulkan melalui sistem dan prosedur yang telah ditetapkan. Dalam Peraturan Daerah tentang Pedoman Pengelolaan Keuangan Daerah, antara lain berupa pemberian pedoman sistem dan prosedur pengelolaan keuangan daerah, mencakup tata cara penatausahaan dan akuntansi, pelaporan dan pertanggungjawaban keuangan daerah. Diantaranya Prosedur Pelaksanaan Penerimaan Pendapatan melalui 
Bendahara Penerimaan, dengan adanya sistem dan prosedur tersebut, setiap SKPD/SLPKD diharapkan mampu mengelola keuangan daerah yang baik dan dapat dipertanggungjawabkan.

Badan Pengelola Pajak dan Retribusi Daerah (BP2RD) merupakan salah satu Satuan Kerja di lingkungan Pemerintah Daerah Kota Manado selaku SKPKD memiliki tugas dan fungsi melaksanakan tugas umum pemerintahan dibidang pendapatan, pengelolaan keuangan dan aset daerah sesuai dengan peraturan perundang-undangan yang berlaku. Mengingat perannya sangat penting dalam mengelola keuangan terlebih khusus dalam hal penerimaan daerah maka perlu adanya sistem dan prosedur yang memadai sebagai salah satu tindakan yang preventif terhadap adanya penyelewengan dan penyalahgunaan dana pembangunan. Berdasarkan hasil wawancara oleh pihak Badan Pengelola Pajak dan Retribusi Daerah Kota Manado, penerimaan pajak parkir dilaksanakan sesuai dengan fungsinya masing-masing. Dokumen-dokumen yang digunakan yaitu Pedoman Pengelolaan Keuangan Daerah (PPKD), Surat Ketetapan Pajak Daerah (SKPD), Surat adanya Kas masuk dan Bukti Setoran. Pemerintah mengeluarkan peraturan dalam negeri tentang tata cara mengelola keuangan yang bertujuan agar masing-masing daerah dapat mengoptimalkan kemampuan yang ada untuk menggali sumber-sumber penerimaan pendapatan asli daerah. Dengan hasil wawancara tersebut sistem penerimaan tersebut memadai atau sesuai dengan peraturan daerah.

Penerapan sistem penerimaan pajak parkir di Kota Manado adalah Self Assesment system yaitu sistem pemungutan pajak yang memberi wewenang penuh kepada wajib pajak untuk menghitung, mempertimbangkan, menyetorkan, dan melaporkan sendiri besarnya utang pajak. Pelaksanaan penerimaan pajak parkir melalui bendahara penerimaan yaitu menerima pembayaran sejumlah uang, memeriksa jumlah uang yang diterima apakah sesuai dengan SPTPD dan nota pajak.Kemudian menyetor penerimaan pajak ke rekening kas daerah (Bank Sulut). Dalam proses pengendalian internal untuk mencegah adanya salah catat yang dalam bidang pembukuan, Badan Pengelola Pajak dan Retribusi Daerah melakukan pemeriksaan ulang antara buku kas umum dan buku besar penerimaan. Sistem yang diterapkan oleh Badan Pengelola Pajak dan Retribusi Daerah telah sesuai dengan Peraturan yang berlaku. Pajak Parkir merupakan salah satu penerimaan daerah yang memberikan kontribusi bagi peningkatan Pendapatan Asli Daerah (PAD), sehingga diharapkan pajak parkir tersebut dapat dijadikan sebagai alternatif pendanaan pemerintah untuk mendukung peningkatan potensi daerah. Ini sangat potensial dalam meningkatkan penerimaan daerah, maka dalam menyelenggarakan Pajak Parkir tersebut, Pemerintah Daerah melalui Dinas Pengelola Pajak dan Retribusi Daerah harus mengawasi proses pelaksanaan Pajak Parkir ini sesuai dengan Peraturan Pemerintah dan Peraturan Daerah yang telah ditetapkan. Dalam pelaksanaan Pajak Parkir tersebut Pemerintah Daerah tentunya mendapat permasalahanpermasalahan, masalah yang di dapat oleh penulis yaitu masih kurang jelas bagaimana sebenarnya sistem dan prosedur pengelolaan keuangan serta sistem penerimaan pajak apakah telah sesuai dengan peraturan yang telah ditetapkan. Kasim (2015) menyatakan permasalahan timbul karena adanya kelemahan dari sistem dan ketidaksesuaian dalam pemenuhan regulasi dan hukum yang mengatur pelaporan keuangan di setiap institusi. Berdasarkan latar belakang yang diuraikan sebelumnya, maka peneliti merumuskan masalah dalam penelitian ini adalah: Apakah sistem penerimaan pajak parkir di kota Manado telah memadai? Sesuai dengan masalah yang dirumuskan, penelitian ini bertujuan untuk menganalisis memadai tidaknya sistem penerimaan pajak parkir di Kota Manado.

\section{TINJAUAN PUSTAKA}

Konsep Akuntansi. Akuntansi merupakan sistem informasi yang menghasilkan sebuah laporan keuangan kepada pihak-pihak terkait yang berkepentingan dengan kegiatan ekonomi dan keadaan suatu badan usaha tertentu (Rudianto, 2013). 
Akuntansi Perpajakan. Pengertian akuntansi pajak menurut Agoes dan Estralita (2013:10) "Akuntansi pajak adalah menetapkan besarnya pajak terutang berdasarkan laporan keuangan yang disusun oleh perusahaan". Akuntansi pajak, merupakan bagian dalam akuntansi yang timbul dari unsur spesialisasi yang menurut keahlian dalam bidang tertentu. Akuntansi pajak tercipta karena adanya suatu prinsip dasar yang diatur dalam UU perpajakan dan pembentukannya terpengaruh oleh fungsi perpajakan dalam mengimplementasikan sebagai kebijakan pemerintah.

\section{Konsep Pajak}

Pengertian Pajak. Defenisi pajak yang dikemukakan oleh Andriani yang dikutip oleh Rahayu (2013:22) yaitu : Pajak adalah iuran kepada negara (yang dapat dipaksakan) yang terutang oleh yang wajib membayarnya menurut peraturan-peraturan dengan tidak mendapat prestasi kembali, yang langsung dapat ditunjuk, dan yang gunanya adalah untuk membiayai pengeluaran-pengeluaran umum berhubung dengan tugas negara untuk menyelenggarkan pemerintahan.

Sistem Pemungutan Pajak. Menurut Siti Resmi (2014:11) sistem pemungutan pajak dibagi menjadi 3 (tiga) yaitu:

1. Official assesment system. Sistem pemungutan pajak yang memberi kewenangan aparatur perpajakan untuk menentukan sendiri jumlah pajak yang terhutang setiap tahunnya sesuai dengan peraturan perundang-undangan perpajakan yang berlaku. Dalam sistem ini, inisiatif serta kegiatan menghitung dan memungut pajak sepenuhnya berada di tangan aparatur perpajakan. Dengan demikian, berhasil atau tidaknya pelaksanaan pemungutan pajak bergantung pada aparatur perpajakan (peranan domian ada pada aparatur perpajakan).

2. Self assesment system. Sistem pemungutan pajak yang memberikan wewenang Wajib Pajak dalam menentukan sendiri jumlah pajak yang terutang setiap tahunnya sesuai dengan peraturan perundang-undangan perpajakan yang berlaku. Dalam sistem ini, inisiatif serta kegiatan menghitung dan memungut pajak sepenuhnya berada di tangan Wajib Pajak. Wajib Pajak dianggap mampu menghitung pajak, mampu memahami undang-undang perpajakan yang sedang berlaku, dan mempunyai kejujuran yang tinggi, serta menyadari akan arti pentingnya membayar pajak. Dengan demikian berhasil atau tidaknya pelaksanaan pemungutan pajak banyak tergantung pada Wajib Pajak sendiri (peranan dominan ada pada Wajib Pajak).

3. With holding system. Sistem pemungutan pajak yang memberikan wewenang kepada pihak ketiga yang ditunjuk untuk menentukan besarnya pajak yang terutang oleh Wajib Pajak sesuai dengan peraturan perundang-undangan perpajakan yang berlaku. Penunjukkan pihak ketiga ini dilakukan sesuai peraturan perundang-undangan perpajakan, keputusan presiden, dan peraturan lainnya untuk memotong serta memungut pajak, menyetor, dan mempertanggungjawabkan melalui sarana perpajakan yang tersedia. Berhasil atau tidaknya pelaksanaan pemungutan pajak banyak tergantung pada pihak ketiga yang ditunjuk.

\section{Pajak Parkir}

Pengertian Pajak Parkir. Pajak parkir yaitu dipungut atas penyelenggaraan tempat parkir di luar badan jalan, baik yang diberikan berkaitam dengan pokok usaha dan yang disediakan termasuk menyediakan tempat untuk kendaraan bermotor. Sedangkan parkir adalah kenyataan tidak adanya kendaraan yang tidak bersifat sementara.

\section{Dasar Pengenaan Pajak Parkir Pajak Parkir}

1. Dasar pengenaan pajak parkir. Dasar pengenaan Pajak Parkir adalah beberapa pembayaran atau yang tergabung dengan tempat parkir. Jumlah yang terdiri dari beberapa 
orang termasuk potongan harga parkir dan hanya yang menerima untuk terima jasa parkir. Dasar pengenaan pajak didasarkan pada klasifikasi tempat parkir, daya tampung dan frekuensi kendaraan bermotor. Setiap kendaraan bermotor yang parkir pada tempat parkir di luar badan jalan akan dikenakan tarif parkir yang ditetapkan oleh pengelola. Tarif parkir ini merupakan pembayaran yang harus diserahkan oleh pengguna tempat parkir untuk pemakaian tempat parkir.

2. Tarif Pajak Parkir. Tarif pajak parkir ditetapkan paling tinggi sebesar tiga puluh persen dan tarif pajak untuk masing-masing daerah ditetapkan dengan Peraturan daerah kabupaten/kota untuk menetapkan tarif pajak yang dipandang sesuai dengan kondisi masing-masing daerah kabupaten/kota diberi kewenangan untuk menetapkan besarnya tarif pajak yang mungkin berbeda dengan kabupaten/kota lainnya asalkan tidak lebih dari $30 \%$.

\section{Pengendalian Internal}

Pengertian Pengendalian Internal. Menurut Romney dan Steinbart (2015:216) pengendalian internal adalah sebuah proses yang diimplementasikan untuk memberikan jaminan yang memenuhi beberapa objektif dari pengendalian internal, diantaranya yaitu menjaga aset, menjaga catatan dalam detail yang cukup untuk pelaporan aset perusahaan yang tepat dan akurat, menyediakan informasi yang akurat dan dapat dipercaya menyiapkan laporan keuangan dengan kriteria yang ditentukan, mendorong dan meningkatkan efisiensi operasional, mendorong ketaatan dalam hal manajerial, dan memenuhi persyaratan dari regulasi dan peraturan yang ada.

Tujuan Pengendalian Internal. Menurut Hery (2013:160), tujuan pengendalian internal tidak lain adalah untuk memberikan jaminan yang memadai bahwa: Aset yang dimilki oleh perusahaan telah diamankan sebagaimana mestinya dan hanya digunakan untuk kepentingan perusahaan semata, bukan untuk kepentingan individu (perorangan) oknum karyawan tertentu. Dengan demikian pengendalian internal diterapkan agar supaya seluruh aset perusahaan dapat terlindungi dengan baik dari tindakan penyelewengan, pencurian, dan penyalahgunaan, yang tidak sesuai dengan wewenangnya dan kepentingan perusahaan informasi akuntansi perusahaan tersedia secara akurat dan dapat diandalkan. Ini dilakukan dengan cara memperkecil resiko baik atas salah saji laporan keuangan yang disengaja (kecurangan) maupun yang tidak di sengaja (kelalaian).

Aktivitas Pengendalian Internal. Aktivitas pengendalian merupakan kebijakan dan prosedur yang dilakukan untuk memastikan bahwa aktivitas dalam mengatasi resiko pengendalian telah dilakukan dalam mencapai tujuan tertentu. Aktivitas pengendalian meliputi : (1) pemisahan fungsi/tugas/wewenang yang cukup; (2) otorisasi transaksi dan aktivitas lainnya yang sesuai; (3) pendokumentasian dan pencatatan yang cukup; (4) pengendalian secara fisik terhadap aset dan catatan; (5) evaluasi secara independen atas kinerja; (6) pengendalian terhadap pemrosesan informasi; dan (7) pembatasan akses terhadap sumberdaya dan catatan.

Komponen Pengendalian Internal. Terdapat 5 komponen Pengendalian Internal menurut Tunggal(2013:196) yaitu:

1. Lingkungan Pengendalian Internal (Control Environment). Lingkungan pengendalian merupakan dasar untuk semua komponen pengendalian internal atau merupakan pondasi dari komponen lainnya. Meliputi beberapa fakor yaitu : (a) integritas dan etika; (b) komitmen untuk meningkatkan kompetensi; (c) dewan manajemen dan komite audit; (d) filosofi manajemen dan jenis operasi; (e) struktur organisasi; dan (f) kebijakan dan praktik sumber daya manusia.

2. Penilaian Risiko (Risk Assesment). Terdiri dari identifikasi resiko. Identifikasi resiko meliputi pengujian terhadap faktor-faktor eksternal seperti pengembangan teknologi, 
persaingan, dan perubahan ekonomi. Faktor internal diantaranya kompetisi karyawan, sifat dari aktivitas bisnis, dan karakterister pengolahan sistem informasi.

3. Aktivitas Pengendalian (Control Activity). Terdiri dari kebijakan dan prosedur yang menjamin karyawan yang melaksanakan arahan manajemen. Aktivitas pengendalian meliputi review terhadap sistem pengendalian, pemisahan tugas dan pengendalian terhadap sistem informasi.

4. Infromasi dan Komunikasi (Information and Communication). Sistem informasi yang relevan dengan tujuan laporan keuangan, yang mencakup sistem akuntansi, terdiri atas metode dan catatan yang dibangun untuk mencatat, mengolah, meringkas, dan melaporkan transaksi entitas (baik peristiwa maupun kondisi) dan untuk memelihara akuntabilitas untuk asset, utang dan ekuitas yang bersangkutan. Kualitas informasi yang dihasilkan dari sistem tersebut berdampak terhadap kemampuan manajemen untuk membuat keputusan semestinya dalam mengendalikan akativitas entitas dan menyiapkan laporan keuangan yang andal. Komunikasi yang mencakup penyediaan suatu pemahaman tentang peran dari tanggung jawab individual berkaitan dengan pengendalian internal terhadap pelaporan keuangan.

5. Pemantauan (Monitoring). Suatu tanggung jawab manajemen yang penting adalah membangun dan memelihara pengendalian internal. Manajemen memantau pengendalian internal untuk mempertimbangkan apakah pengendalian tersebut dimodifikasi sebagaimana mestinya jika perubahan kondisi menghendakinya. Pemantauan adalah proses penentuan kualitas kinerja pengendalian internal sepanjang waktu. Pemantauan ini mencakup penentuan desain dan operasi pengendalian tepat waktu dan pengambilan tindakan koreksi.

\section{METODE PENELITIAN}

\subsection{Jenis Penelitian}

Jenis penelitian ini menggunakan jenis penelitian kualitatif deskriptif. Jenis penelitian ini menggambarkan secara sistematis mengenai fakta, situasi dan aktivitas yang berkaitan tentang penerapan akuntansi penerimaan pajak parkir pada kantor badan pengelolaan pajak dan retribusi daerah Kota Manado.

\subsection{Prosedur Penelitian}

1. Persiapan. Mengidentifiikasi masalah terhadap objek yang akan diteliti.

2. Wawancara. Pada tahap ini dilakukan melalui tatap muka dan tanya jawab langsung dengan pegawai atau pimpinan yang ada di kantor tersebut untuk meminta informasiinformasi yang terkait dengan judul penelitian.

3. Mengolah data. Jika semua data yang diperlukan telah lengkap, maka akan dilakukan pengolahan data.

4. Penarikan kesimpulan dan saran. Penulis menarik kesimpulan dan saran sesuai dengan pembahasan yang ada dan objek yang diteliti.

\subsection{Metode Pengumpulan Data}

Jenis Data. Jenis data yang digunakan penulis Data kualitatif yaitu jenis data yang dinyatakan dalam bentuk kalimat atau uraian, data ini tidak dapat diukur dan dianalisis secara langsung dengan teknik statistik, tetapi harus diolah dulu menjadi kata-kata yang dapat dicerna.

Sumber data. Sumber data yang digunakan penulis Data Primer dan Data Sekunder. Data Primer adalah data yang langsung dikumpulkan oleh penulis dari objek yang akan diteliti yaitu dari perusahaan tempat penelitian dilaksanakan. Contoh dari data primer adalah wawancara. Data Sekunder berupa informasi-informasi tentang objek yang diteliti melalui studi dokumentasi dengan mempelajari berbagai tulisan dalam buku, internet, jurnal yang berhubungan dengan penelitian. 
Teknik Pengumpulan Data. Teknik pengumpulan data adalah metode atau suatu gambaran kompleks, meneliti kata-kata, laporan terinci dari pandangan responden, dan melakukan studi pada situasi yang alami. Teknik pengumpulan data yang dilakukan adalah wawancara untuk mengumpulkan informasi dengan cara tanya jawab anatara peneliti dengan informan atau subjek penelitian. Dan data yang diperlukan yaitu data yang berhubungan dengan penelitian.

Metode analisis. Metode analisis data yang digunakan dalam penelitian ini adalah metode analisis deskriptif. Metode analisis ini dimulai dengan langkah menumpulkan dan menyaring keterangan-keterangan yang diperoleh secara menyeluruh dan detail, kemudian diuraikan sehingga diperoleh gambaran yang jelas.

\section{HASIL ANALISIS DAN PEMBAHASAN}

\subsection{Sejarah Singkat Badan Pengelola Pajak dan Retribusi Daerah}

Badan Pengelola Pajak dan Retribusi Daerah Kota Manado dibentuk berdasarkan Peraturan Walikota Manado Nomor 61 Tahun 2016 Tentang kedudukan, susunan organisasi, tugas dan fungsi serta tata kerja badan pengelola pajak dan retribusi daerah kota manado tipe A terdapat pada pasal 2 yaitu Badan Pengelola Pajak dan Retribusi Daerah merupakan unsur penunjang urusan pemerintahan bidang pengelolaan pajak dan retribusi daerah. Badan Pengelola Pajak dan Retribusi Daerah dipimpin oleh yang berkedudukan dibawah dan bertanggungjawab kepada walikota melalui Sekretaris Daerah.

\subsection{Hasil Pembahasan}

Sistem Penerimaan Pajak Parkir di Kantor Badan Pengelola Pajak dan Retrribusi Daerah Kota Manado. Penerimaan Pajak Parkir pada Badan Pengelola Pajak dan Retribusi Daerah Kota Manado dilaksanakan sesuai dengan fungsinya masing-masing. Sistem yang di pakai dalam penerimaan Pajak Parkir di Badan Pengelola Pajak dan Retribusi Daerah Kota Manado adalah Self Assessment System yaitu metode yang memberikan wewenang, tanggung jawab, kepercayaan yang besar kepada wajib pajak untuk mempertimbangkan besarnya pajak yang harus di bayar karena semua proses dalam pemenuhan kewajiban perpajakan dilakukan sendiri oleh wajib pajak dan sesuai dengan undang-undang perpajakan yang berlaku. Prosedur sistem penerimaan Pajak Parkir di Badan Pengelola Pajak dan Retribusi Daerah Kota Manado adalah sebagai berikut:

1. Pihak terkait : (a) PPK-SKPD; (b) Pengguna anggaran (PA); (c) Bendahara penerimaan; dan (d) BUD (BANK).

2. Dokumen yang digunakan : (a) Surat Pemberitahuan Pajak Daerah (SPTPD) Pajak Parkir; (b) Surat Tanda Setoran (STS); dan (c) Nota Kredit Bank.

3. Catatan yang digunakan : (a) Buku Besar; dan (b) Buku Besar Pembantu.

4. Deskripsi Prosedur. Pelaksanaan sistem penerimaan pajak Parkir di kota Manado dilakukan melalui bendahara penerimaan dan pendapatan daerah melalui bank pemerintah yang ditunjuk: (1) Prosedur Penerimaan Pajak Parkir melalui bendahara penerimaan; dan (2) Prosedur Penerimaan Pajak Parkir melalui Bank Kas Daerah (BANK SULUT). 
Tabel 1. Penerimaan Pajak Parkir Pada Badan Pengelola Pajak dan Retribusi Daerah Kota Manado

\begin{tabular}{|c|c|c|c|}
\hline No & Pelaksanaan & Langkah & Aktivasi \\
\hline 1. & PPKD & 1 & $\begin{array}{l}\text { Menyerahkan surat yang telah dikeluarkan } \\
\text { oleh PPK yaitu penyetoran pajak dan nota } \\
\text { pajak daerah serta SPTPD. }\end{array}$ \\
\hline 2. & PPK & 2 & $\begin{array}{l}\text { Kemudian menyerahkan surat penyetoran } \\
\text { pajak dan nota pajak daerah kepada wajib } \\
\text { pajak }\end{array}$ \\
\hline 3. & Wajib Pajak & 3 & $\begin{array}{l}\text { Mengisi SPTPD dan nota pajak daerah sesuai } \\
\text { income yang diterima }\end{array}$ \\
\hline 4. & SKPD & 4 & $\begin{array}{l}\text { Setelah wajib pajak mengisi hasil pajak yang } \\
\text { diterima dan nota pajak, wajib pajak menerima } \\
\text { surat SPTPD }\end{array}$ \\
\hline & & 5 & $\begin{array}{l}\text { Kemudian wajib pajak menyetor besarnya } \\
\text { pajak yang diterima kepada pihak bank (Bank } \\
\text { Sulut) }\end{array}$ \\
\hline 5. & $\begin{array}{l}\text { Bendahara } \\
\text { Penerimaan }\end{array}$ & 6 & $\begin{array}{l}\text { Memeriksa jumlah setoran pajak dengan } \\
\text { SPTPD. } \\
\text { Membuat Surat bukti adanya setoran pajak. }\end{array}$ \\
\hline
\end{tabular}

(Sumber: Badan Pengelola Pajak dan Retribusi Daerah Kota Manado)

Tabel 1 menujukkan bahwa langkah dan prosedur penerimaan pada BP2RD kota Manado dilakukan oleh beberapa pelaksana dan dokumen yang digunakan yaitu Pedoman Pengelolaan Keuangan Daerah (PPKD), Surat Ketetapan Pajak Daerah (SKPD.

\section{Analisis Sistem Penerimaan Pajak Parkir di Kantor Badan Pengelola Pajak dan Retribusi Daerah Kota Manado}

1. Sistem Prosedur Penerimaan Pajak Parkir di Badan Pengelola Pajak dan Retribusi Daerah Kota Manado telah memadai dan sesuai dengan Permendagri Nomor 59 Tahun 2007 pada surat edaran tentang sistem dan pengelolaan keuangan daerah yang berisi ketentuan tentang Prosedur Penerimaan Kas, Penerimaan Kas pada BP2RD diserahkan ke rekening umum daerah pada Bank Pemerintah yang telah ditunjuk, setelah bank menerima sejumlah kas kemudian bank mengirim nota kredit bahwa adanya bukti setoran ke pihak yang melaksanakan.

2. Setoran pajak berupa uang dari Wajib Pajak diverifikasi sesuai SPTPD kemudian bendahara penerima membuat Bukti Surat Tanda Setor.

3. Dan jika Wajib Pajak membayar langsung ke Bank Sulut, pihak bank membuat slip bukti adanya setoran pada bank sebanyak 2 lembar yang akan diserahkan kepada Wajib Pajak. Kemudian slip setoran tersebut salah satunya diberikan kepada Bendahara Penerimaan, kemudian membuat surat sebagai tanda bukti adanya pembayaran pada kas daerah. 
Tabel 2. Analisis Sistem Penerimaan Pajak Daerah Pada Badan Pengelola Pajak dan

Retribusi Daerah Kota Manado

\begin{tabular}{|c|c|c|c|}
\hline No & $\begin{array}{l}\text { Permendagri } 59 \\
\text { Tahun } 2007 \text { Pasal } \\
89 \text { (dalam surat } \\
\text { edaran) }\end{array}$ & Hasil Penelitian & Ket \\
\hline 1. & $\begin{array}{c}\text { Pihak / Fungsi } \\
\text { Terkait }\end{array}$ & $\begin{array}{l}\text { Yang bertugas dalam mencatat yaitu, } \\
\text { Pengguna Anggaran, serta bidang yang } \\
\text { menerima setoran yaitu bendahara, Surat } \\
\text { pemberitahuan pajak, dan bidang akuntansi. }\end{array}$ & Sesuai \\
\hline 2. & Aktivasi & $\begin{array}{l}\text { Untuk proses penyetoran penerimaan yaitu } \\
\text { adanya bukti uang diterima/masuk, dan nota } \\
\text { pembayaran dari bank. }\end{array}$ & Sesuai \\
\hline 3. & Dokumen & $\begin{array}{l}\text { Terdapat dokumen yang digunakan dalam } \\
\text { penyetoran yaitu : (a) SPTPD dan Parkir; (b) } \\
\text { Surat Bukti Setoran; dan } \\
\text { Pembayaran dari Bank }\end{array}$ & Sesuai \\
\hline
\end{tabular}

(Sumber: Data Diolah,2018)

Tabel 2 menunjukkan bahwa sistem dan prosedur penerimaan Retribusi pada Kantor Badan Pengelola Pajak dan Retribusi Daerah Kota Manado dilakukan oleh beberapa pihak/fungsi yang terkait, aktivasi dan dokumen yang digunakan telah sesuai dengan peraturan yang berlaku.

\section{KESIMPULAN DAN SARAN}

\subsection{Kesimpulan}

Berdasarkan hasil analisis dan pembahasan mengenai sistem penerimaan Pajak Parkir di Kota Manado, maka penulis menarik kesimpulan yaitu sebagai berikut:

1. Sistem Penerimaan Pajak Parkir di Badan Pengelola Pajak dan Retribusi Parkir di Kota Manado menggunakan Self Assessment System yaitu suatu metode yang memberikan wewenang, tanggung jawab, kepercayaan yang besar kepada wajib pajak untuk mempertimbangkan besarnya pajak yang harus di bayar.

2. Pelaksanaan penerimaan Pajak Parkir pada Kantor Badan Pengelola Pajak dan Retribusi Parkir di Kota Manado telah sesuai dengan peraturan yang berlaku.

3. Pelaksanaan dalam sistem pengendalian internal pada Badan Pengelola Pajak dan Retribusi Parkir di Kota Manado telah memadai dalam bidang akuntansi khususnya bidang pembukuan dan pencatatan ke dalam buku besar.

4. Untuk menghindari adanya kesalahan pencatatan yang dilakukan oleh pihak bagian pembukuan, setiap akhir bulan sebelum melakukan tutup buka besar Badan Pengelola Pajak dan Retribusi Daerah memeriksa kembali antara buku kas umum dan buku besar penerimaan/pendapatan.

\subsection{Saran}

Berdasarkan hasil penelitian dalam menganalisis pelaksanaan penerimaan Pajak Parkir beserta sistem dan prosedur penerimaannya, maka penulis akan memberikan saran yang dapat bermanfaat bagi perusahaan yaitu:

1. Khsusunya Badan Pengelola Pajak dan Retribusi Daerah harus perlu terus mengupdate Peraturan Menteri Dalam Negeri atau peraturan pemerintah daerah yang berlaku mengenai sistem penerimaan pajak agar pelaksanaannya lebih baik dan efektif. 
2. Bagi pihak Badan Pengelola Pajak dan Retribusi daerah agar lebih meningkatkan lagi kualitas pelayanan dan sosialisasi kepada masyarkat tehadap pentingnya membayar pajak.

3. Sistem penerimaan pajak parkir yang telah sesuai dengan peraturan daerah yang cukup efektif harus terus dipertahankan dan pengawasannya lebih ditingkatkan.

\section{DAFTAR PUSTAKA}

Agoes, Sukrisno dan Estralita Trisnawati. 2013. Akuntansi Perpajakan Edisi 3. Jakarta:Salemba Empat

Aiga, Islamiyah, Putri, (2016). Analisis Sistem Informasi Akuntansi Penerimaan dan Pengeluaran Kas Pada RSUD Dr. H. Slamet Martodirdjo Pamekasan. Fakultas Ekonomi dan Bisnis, Universitas Muhammadiyah Malang.

Amin Widjaja Tunggal. 2013. Terori dan Praktek Auditing. Jakarta Harvarindo

Amalia, Fitri, Dwi. (2017). Sistem Pemungutan Pajak Parkir dan Analisis Kinerja Pemungutan Pajak Parkir pada DPPKAD Kabupaten Semarang. Fakultas Hukum UNNISSULA Semarang

Amrijaya, 2018. Analisis Sistem Pengendalian Intern Pemungutan Pajak Daerah Untuk Mengetahui Tingkat Efektifitas Pendapatan Daerah Pada Pemerintah Daerah Kota Kediri. Fakultas Ekonomi. Universitas Islam Kediri

Bodnar, Hopwood. 2013, Sistem Informasi Akuntansi, edisi kedua Yogyakarta:BPFE

Commite of Sponsoring Organization of the Treadway Commission (COSO), 2013. Pengendalian Internal dan Manajemen Risiko. Jakarta: Yayasan Pendidikan Internal Audit (YPIA)

Damayanti Theresia Woro dan Supramono, Prof. 2015. Perpajakan Indonesia Mekanisme dan Perhitungan. Andi. Yogyakarta

Francis Pol C. Lim, (2013), Impact Of Information Technology on Accounting Systems. AsiaPacific Journal of Multimedia Services Convergent with Art, Humanities and Sociology Vol. 3 (2):93-16

Frenky, Furwanto, 2013. Pengaruh Penerimaan Pajak Parkir dan Retribusi Parkir Terhadap Pendapatan Asli Daerah Kota Pekanbaru.Fakultas Ekonomi. Universitas Islam Negeri Sultan Syarif Kasim Riau

Fajrina, Icha, 2017. Analisis Penerimaan Retribusi Parkir dan Pajak Parkir di Dinas Pendapatan Asli Daerah Kota Palembang. STIE MDP

Halim, Abdul, (2013). Akuntansi Keuangan Daerah. Salemba Empat Jakarta

Hery, 2013. Auditing (Pemeriksaan Akuntansi 1), Cetakan Pertama, Jakarta :CAPS (Center of Academic Publishing Service)

Irma, Wati, (2014). Analisis Prosedur Akuntansi Penerimaan Pajak Daerah Pada PPKSKPD Dinas Pengelolaan Keuangan Daerah Kota Tangerang. Fakultas Ekonomi dan Bisnis Usakti Tangerang

Irma, Marlinang, 2017. Analisis Penerimaan Pajak Parkir Terhadap Pendapatan Asli Daerah Pada Dinas Pendapatan Daerah Pemerintah Kota Medan. Fakultas Ekonomi. Universitas HKBP Nommensen

Jauharul, Maknunah, (2015). Analisis Sistem Informasi Penerimaan dan Pengeluaran Kas pada Lembaga Pendidikan. Fakultas STIKI Malang

Kasim, Azhar, 2015. Buerauctratic Reform and Dynamic Governance for Combating Corruption: The Challenge for Indonesia:International Journal of Administration Science and Organization 20 (No.1):18-22 
Krismiaji, 2013. Sistem Informasi Akuntansi. Ed. Ketiga, Sekolah Tinggi Ilmu Manajemen YKPN, Yogyakarta.

Kobandaha, Rezlyanti (2016), Analisis Efektivitas, Kontribusi dan Potensi Pajak Reklame dan Pajak Hotel Terhadap Pendapatan Asli Daerah Kota Kotamobagu. Jurnal EMBA : Fakultas Ekonomi dan Bisnis, Universitas Sam Ratulangi.

Lamia, Alfan, (2015), Analisis Efektivitas dan Kontribusi Pemungutan Pajak Restoran, Pajak Reklame, dan Pajak Penerangan Jalan Pada Pendapatan Asli Daerah Kabupaten Minahasa Utara. Jurnal EMBA: Fakultas Ekonomi dan Bisnis, Universitas SamRatulangi, Manado.

Mardiasmo. 2013. Perpajakan, Edisi Revisi. Andi. Yogyakarta

Mardiasmo. 2016. Perpajakan, Edisi Terbaru, Andi, Yogyakarta

Mardiasmo. 2018. Perpajakan, Edisi Terbaru, Andi Yogyakarta

Muljono, Djoko 2014. Akuntansi Pajak. Jakarta:Salemba Empat

Mulyadi, 2013. Sistem Akuntansi. Jakarta:Salemba Empat

Nur, Azizah, Sulinda (2014). Analisis Sistem Pengendalian Internal Pada Sistem Penerimaan Kas Pajak Daerah. Universitas Muhammadiyah Malang

Nur, Furqani, Sahni, (2017). Pengaruh Sistem Pengendalian Intern Terhadap Penerimaan Kas Pada Perusahaan Daerah Air Minum (PDAM) Kabupaten Bantaeng. Fakultas Ekonomi, Universitas Negeri Makassar

Nanda, Kusuma, Wardana, 2013. Peranan Pajak Parkir dalam menunjang Peningkatan Pendapatan Asli Daerah di Kota Malang. Fakultas Ekonomi. Universitas Negeri Malang.

Peraturan Pemerintah Nomor 65 Tahun 2001 tentang Pajak Daerah

Peraturan Daerah Kota Manado Nomor 08 Tahun 2002 tentang Pajak Parkir, Manado.

Peraturan Menteri Dalam Negeri No. 59 Tahun 2007 tentang Pedoman Pengelolaan Keuangan Daerah.

Putri, Dyah, Ayu, Lestari, (2017). Analisis Penerimaan Pajak Daerah dan Retribusi Daerah Terhadap Pendapatan Asli Daerah Kabupaten Langkat Stabat. Fakultas Ekonomi dan Bisnis, Universitas Medan Area Medan

Rizaldy, Muhammad Faishal (2017), Kontribusi Retribusi Parkir dan Pajak Parkir Terhadap Pendapatan Asli Daerah Di Kabupaten Banjar Provinsi Kalimantan Selatan Tahun 2014-2016, Universitas Muhammadiyah Yogyakarta.

Rahayu, Kurnia, Siti, 2017. Perpajakan (konsep dan aspek formal), Edisi Revisi, Rekayasa Sains Bandung

Rudianto, 2013. Akuntansi Manajemen Informasi untuk Pengambilan Keputusan Strategis. Jakarta: Erlangga

Resmi, Siti, 2014. Perpajakan Teori dan Kasus Edisi 4. Jakarta: Salemba Empat

Romney, Marshall B, dan Steinbart John Paul, 2015. Accounting Information System, 13th ed.England: Pearson Educational Limited.

Rizki, Novelia, Hanydar, 2017. Analisis Strategi Penguatan Penerimaan Pajak Parkir Kabupaten Semarang Tahun 2010-2016. Fakultan Ekonomi. Universitas Negeri Semarang

Soemitro, Rochmat. Prof. 2013. Dasar-dasar Hukum Pajak dan Pajak Pendapatan, Bandung: PT Eresco

Siahaan, Marihot, 2016. Pajak Daerah dan Retribusi Daerah, PT. Raja Grafindo Persada Jakarta

Supramono, Theresia, W, D, 2015. Perpajakan Indonesia mekanisme \& perhitungan, Edisi Revisi, Andi Yogyakarta

Subadriyah, 2017. Pajak Penghasilan, Pustaka Pelajar dan UNISNUPRESS 
Sylvianti, Anggraini, 2017. Analisis Penerapan Sistem Informasi Akuntansi Penerimaan dan Pengeluaran Kas Pada PT Panin Dai-Ichi Life Cabang Palembang. Fakultas Ekonomi. STIE Multi Data Palembang

Tunggal, Widjaja, Amin. 2013. Terori dan Praktek Auditing. Jakarta Harvarindo

Tika, Sugiharti, 2013. Analisis Potensi dan Kendala Serta Optimalisasi Pajak Parkir Terhadap Penerimaan Pajak Daerah di Provinsi DKI Jakarta. Fakultas Ekonomi. Universitas Indonesia

Undang-Undang Nomor 6 Tahun 1983 tentang Ketentuan Umum dan Tata Cara Perpajakan

Undang-Undang Republik Indonesia Nomor 28 Tahun 2009 tentang Pajak Daerah dan Retribusi Daerah

Undang-Undang Nomor 18 Tahun 1997 tentang Pajak Daerah dan Retribusi Daerah

Undang-Undang Nomor 28 Tahun 2009 Pasal 1 angka 31 dan 32 tentang Pajak dan Pajak Parkir

Waren dan Rawung, 2014. Pengantar Akuntansi. Edisi 21. Salemba Empat, Jakarta 